\title{
Thoughts on the Mixed Learning Model of College Mathematics SPOC Based on the Concept of "Internet Plus Education"*
}

\author{
Xiuyun Xia \\ School of General Education \\ Hunan University of Information Technology \\ Changsha, China 410005
}

\begin{abstract}
With the advent of the Internet era, "Internet plus education" is the inevitable trend of higher education development. The introduction of SPOC mixed learning mode brings new opportunities for classroom teaching reform. This paper first introduces the current situation and problems of college mathematics classroom. Secondly, aiming at the above problems, it explores the SPOC mixed learning mode of College Mathematics based on the concept of "Internet plus education" and the specific implementation methods of the classroom. Finally, it expounds the benefits of SPOC teaching mode.
\end{abstract} mixed

Keywords-“Internet education"; college mathematics; SPOC;

\section{INTRODUCTION}

The Ministry of Education has clearly stated the strategic deployment [1] [2] [4] of the "The information technology has a revolutionary influence on the development of education, and must pay great attention to promoting modernization of the content of education, the means of teaching and the method" in "Outline of National medium-and long-term Education Reform and Development Plan (2010-2020)" and the 13th Five-Year Plan for Education Informatization. In recent years, with the rapid development of information technology, the Internet has penetrated into people's learning and life. The MOOC platform suitable for the use of higher education informatization is surging. SPOC is the perfection and transcendence of MOOC, which effectively promotes the informatization reform of higher education. SPOC is the abbreviation of small private online course, which means "small private online course" in Chinese. This concept was first proposed and used by Professor Armand Fox of the University of California, Berkeley [6]. "Internet + education" is a new educational concept. It has opened up a new vision and direction for education, provided new ideas and new ideas for improving the quality of education, which can realize a new pattern of open and diversified education, and bring new opportunities and new challenges for the reform of college mathematics teaching.

In view of the new requirements for the integration of the

*Fund: 2018 school level demonstration course support project of Hunan University of Information Technology; the support project of 2018 provincial education reform project (No.: 958).
Internet age and higher education, some new research hotspots have emerged in the teaching reform of College Mathematics Based on SPOC teaching mode. For example, Professor Cao Weifeng conducts SPOC practice research on higher vocational mathematics courses in the article "Research and practice of SPOC teaching mode in Higher Vocational Mathematics" [5]; Professor Zhao Liang and other professors studied the application of SPOC teaching mode in the Cultivation of Applied Talents in Colleges and universities [6]; Professor Huang Chunfang introduced SPOC platform from the second classroom to the corresponding research in the article Exploration of the all-round education mode of" competition + Classroom "based on SPOC platform to carry out the corresponding research [7]. However, in view of how to carry out SPOC mixed learning mode in College Mathematics to promote the construction of new knowledge, that is, under the background of "Internet +" deep integration, the research on the innovative ability path of classroom education and teaching based on SPOC platform and the new mode of online and offline mixed education are not seen in the recent literature. Therefore, combining the idea of "Internet + education" to carry out the research of SPOC mixed practice teaching in university mathematics is of great significance.

\section{The CurRent Situation AND Problems of College MATHEMATICS CLASS}

\section{A. The Importance of College Mathematics Courses}

College mathematics is an important compulsory basic discipline for non mathematics majors in Colleges and universities [1] [3]. There are three aspects of its function, It has three main functions: one is the foundation of each professional course, providing the necessary mathematical knowledge; the second is to provide a good environment and carrier for the cultivation of students' innovation ability, etc., (especially the ability to analyze and solve problems); the third is to provide the necessary mathematical tools for college students to serve the society. Modern engineering science needs more and more mathematics, more and more modernization, which involves a lot of concepts, theories and methods of mathematics. Every progress and innovation of engineering technology is closely related to good mathematical 
is introduced into the mathematics classroom of our school, changing the situation of separation of teachers and students after class, exploring personalized practice teaching, cooperative learning mode, and strengthening personalized learning strategy guidance. Based on the individualized learning basis of students, a small learning team should be allocated reasonably. Each small team should arrange a group leader to supervise each link online and offline, give each student individualized learning guidance, and improve the learning effect of students.

From the current situation of college mathematics teaching, the application-oriented talents under the current teaching mode are seriously out of line with the requirements of the development of the times, which is difficult to meet the needs of the society for comprehensive innovative talents. The reasons for the problems are as follows: First, the content of college mathematics curriculum emphasizes the theory, law and deduces the, which does not reflect the nature of the times and information. The second is that the college mathematics curriculum can't meet the needs of the application-oriented undergraduate talents training for mathematics knowledge and skills training, etc., The third is that the college mathematics teaching mode is too traditional and not innovative, which leads to low interest of students; the fourth is that the college mathematics curriculum fails to meet the professional needs and students' needs well, and the teaching mode is not suitable for the cultivation of students' engineering practice ability and innovation ability. Therefore, it is imperative to reform the teaching of college mathematics based on the concept of "Internet + education".

\section{EXPLORING THE MIXED LEARNING MODEL OF COLLEGE MATHEMATICS SPOC UNDER THE CONCEPT OF "INTERNET PLUS EDUCATION"}

With the popularity of the Internet, the development of all walks of life is bound to be inextricably linked to the Internet. Therefore, it is necessary to carry out the teaching reform of college mathematics education based on "Internet + education". The following explores the college mathematics SPOC mixed learning mode from several aspects to achieve the corresponding effect.

\section{A. Perfecting the Teaching Resource Base of Mathematics Course by Using the Deep Fusion of Information}

With the help of the network teaching resources platform of our university, it is imperative to create a batch of university mathematics teaching resources uploaded to the CNSPOC platform of college teaching resources, reasonably allocate students' online and offline learning content, improve the timeliness of the course, establish a continuous learning mode of university mathematics pre class preview, interaction in class, and consolidation of online and offline mixed guidance after class, promote the extension and expansion of the course, so as to improve teaching efficiency and teaching effect.

\section{B. Enhancing Students' Personalized Learning Based on the "Internet Plus Education" Concept}

Based on the idea of "Internet plus education", the SPOC mixed theory and practice integrated practical teaching mode

\section{Enhancing the Cultivation of Innovation Ability}

First of all, according to the "basic requirements of teaching" issued by the Ministry of education, students are encouraged to cooperate with teachers online and offline, to effectively construct the university mathematics knowledge system, and to promote the cultivation of students' ability. Secondly, it is required to use SPOC platform to update the teaching resources of College Mathematics in time, to adapt to the characteristics of the information age and the latest industry concept, to cultivate students' practical ability and innovative thinking. In addition, with the help of video resources of SPOC platform, the vivid presentation of specific cases combining university mathematics knowledge points and industry can stimulate students' learning initiative. It is required to make online live broadcast of offline classroom, timely guide students to transfer what they have learned to real life, hire relevant experts to comment and guide, promote the cultivation of students' innovation ability, and form a broad and professional knowledge structure of students.

\section{THE IMPLEMENTATION OF THE SPOC LEARNING MODE OF UNIVERSITY MATHEMATICS UNDER THE CONCEPT OF "INTERNET PLUS EDUCATION"}

\section{A. Classroom Design of SPOC Learning Mode in College Mathematics}

First of all, classroom design is aimed at cultivating ability, Highlight the design idea of taking "Internet education" as the concept, taking information as the means, taking the professional demand as the guide, taking the student as the main body, the overall curriculum design is based on the university's mathematical knowledge goals, and the cultivation of students' innovative ability is emphasized through the practical application of case-oriented, the combination of theory and practice.

Secondly, the specific design steps are to divide the course into three teaching modules: before class, during class and after class. Combined with the form of information fusion education, students can carry out online learning (Preview), online and offline mixed teaching in class and live "consolidation + expansion" learning after class. The teaching method of integrating theory and practice is adopted to cultivate students' ability of logical thinking and innovation.

Then, it is the implementation requirements of curriculum content. In terms of the selection of teaching content, based on the requirements of our school's talent training program and syllabus, guided by the actual cases, the theoretical knowledge 
is integrated into the mathematical model, At the same time, it is necessary to assist in the use of information-based teaching methods, to promote the diversity of classroom teaching and to stimulate the effectiveness of the students' learning.

\section{B. Implementation of SPOC Mixed Learning Mode in Teaching}

First, it is to use SPOC platform to teach the corresponding line before class. According to the requirements of college mathematics talent training objectives, teachers prepare online teaching resources, students learn, expand learning and training tests before class, teachers timely understand students' mastery, know what they know, and ensure that offline learning is more targeted.

Second, it is proposed to carry out the corresponding online and offline mixed in class teaching. In class implementation steps: classroom guidance, classroom interactive discussion, classroom evaluation. The specific implementation process: In the form of sub-project group, the teacher is the technical guidance, the students in the group form the project group member, the group member is a team, stimulates the student team cooperation ability and the initiative participation enthusiasm.

Third, it is to set up extracurricular interest groups to carry out online and offline learning after class. College mathematics is an important basic course closely connected with the major, which is an important supporting course of the professional course. The extracurricular interest group is carried out in the form of school mathematics association, combined with mathematics competitions, with corresponding task requirements arranged, teachers' guidance in the whole process, excellent students as the president, to ensure the enthusiasm and initiative of students' online and offline learning and exchange.

Fourth, the assessment and evaluation are carried out in a variety of ways, which combines online assessment and offline assessment. The final assessment and evaluation will be obtained by calculating the results of online assessment and offline assessment and evaluation according to a certain proportion of weight. The combination of online and offline assessment forms focuses on the process assessment mode to ensure the motivation of students' continuous learning. At the same time, it also ensures the continuous guidance of the instructor to the whole teaching process and the whole process can be controlled. Online assessment is based on the learning of curriculum teaching resources (video, lesson plan, PPT, MOOC), online homework, testing, etc., while offline assessment is based on attendance, classroom performance, offline homework, stage quiz, final exam, etc. as the key evaluation indicators.

\section{BENEFITS BROUGHT BY THE DEVELOPMENT OF SPOC LEARNING MODE OF UNIVERSITY MATHEMATICS}

Through the practice of SPOC learning mode of college mathematics, it can enrich the traditional classroom teaching form, promote the diversification of classroom teaching, explain the characteristics of the deep integration of information technology and higher education, improve the teaching efficiency and teaching effect, stimulate students' learning initiative, promote students' own learning development, and make full use of the combination of Internet and education to better serve the teaching. This is helpful to explore the reform of mathematics classroom teaching in applied undergraduate universities and promote the Internet to better serve the teaching, so as to form the teaching strategies and methods of mathematics education under the background of the Internet.

\section{CONCLUSION}

Based on the concept of "Internet plus education", this paper probes into the mixed teaching mode of college mathematics SPOC, first introduces the present situation and problems of university mathematics classroom, and then puts forward the mixed learning mode of college mathematics SPOC and the concrete implementation method of classroom in view of the above problems, and finally expounds the benefits brought by the SPOC teaching mode. Through the organic integration of teaching and information technology, the reform of mathematics course teaching method, teaching content and assessment method, improve the teaching quality, for the college mathematics curriculum teaching reform to provide new ideas and new thinking.

\section{REFERENCES}

[1] Liu Lihong. How to Improve Mathematics Teaching Under the Environment of "Internet + " Education[J]. Information Technology and Teaching, 2019, the $17^{\text {th }}$ issue. (in Chinese)

[2] Guo Shaoqing. "Internet + Education" Appeal to the Development of Educational Theory [J]. Journal of East China Normal University Education Science Edition)2019, the $4^{\text {th }}$ issue. (in Chinese)

[3] Hua Jian, Zhu Qing Fang. Higher Mathematics Teaching Under the "Internet + Education" Thinking Mode[J].Science \& Education and Article Collects, 2019, the 461st issue. (in Chinese)

[4] Yu Shengquan, Wang A'xi. The Way of "Internet + Education" Transformation [J]. China Educational Technology, 2016, the 10th issue. (in Chinese)

[5] Cao Weifeng. Research and Practice of SPOC Teaching Mode in Higher Vocational Mathematics [J]. Journal of Reading and Writing, 2018 , the $7^{\text {th }}$ issue. (in Chinese)

[6] Zhao Liang, Zhang Wei. Research on the Application of SPOC Teaching Mode in the Cultivation of Applied Talents in Colleges and Universities[J]. Journal of Heilongjiang Vocational Institute of Ecological Engineering, 2018, the $5^{\text {th }}$ issue (in Chinese)

[7] Huang Chunfang. Exploration on the Omni-directional Education Mode of "Competition +Classroom" Based on SPOC Platform [J].Software Application, 2018, the $8^{\text {th }}$ issue. (in Chinese) 